\title{
Chapter 6 \\ Railway Disturbances on Wildlife: \\ Types, Effects, and Mitigation Measures
}

\author{
Priscila Silva Lucas, Ramon Gomes de Carvalho and Clara Grilo
}

\begin{abstract}
In this chapter, we review the level of disturbance caused by railways due to noise and vibration, air, soil and water pollution, and soil erosion. There is evidence that soil and hydrology contamination may affect vegetation and aquatic fauna while noise can affect terrestrial vertebrates. In fact, noise, light, and vibration due to railways have been observed to reduce the abundance and richness of some insects, amphibians, and birds, and to cause avoidance behaviour on predators. Interestingly, reptiles, some bird species, small mammals, and large mammals seem to ignore rail traffic and benefit from the vegetation planted in the railway verges that provide food and shelter. Some engineering structures have been implemented to reduce the effects of railway disturbance: rail fastenings, rail dampers, under-sleeper pads, and noise barriers are applied to minimize noise and vibration; washing with water and cleaning the ballast are used to mitigate soil pollution; and grass plantation, the use of gypsum and application of compost/mulch coverage, are applied to control soil erosion.
\end{abstract}

Keywords Noise and vibration - Air and soil pollution - Water pollution - Soil erosion - Terrestrial vertebrates $\cdot$ Species richness $\cdot$ Avoidance effect

\section{Introduction}

The construction and operation of railways implies changes in the surrounded landscape that alter the microclimate, soil, and hydrological dynamics, contributing to the degradation of the natural habitat for many species (Forman and Alexander 1998; Eigenbrod et al. 2009). During operation, the main disturbances caused by railways are air, soil and water pollution, as well as noise and vibration, which

\footnotetext{
P.S. Lucas $(\bowtie) \cdot$ R.G. de Carvalho · C. Grilo

Centro Brasileiro de Estudos em Ecologia de Estradas,

Universidade Federal de Lavras, Lavras 37200-000, Brazil

e-mail: prilucass@gmail.com

C. Grilo
}

Setor Ecologia, Departamento Biologia, Universidade Federal

de Lavras, Lavras 37200-000, Brazil

(C) The Author(s) 2017

L. Borda-de-Água et al. (eds.), Railway Ecology,

DOI 10.1007/978-3-319-57496-7_6 
may alter species richness and species abundance (e.g. Penone et al. 2012; Clauzel et al. 2013). In this chapter, we review these disturbance sources, their effects on wildlife and the main actions to avoid or minimize their effects.

\section{Main Railway Disturbances: Noise and Vibration, and Air, Soil and Water Pollution}

The two most known disturbances of railways are the noise and vibrations caused by passing trains. However, railways are also responsible for a large amount of emissions that cover a wide range of pollutants and toxic substances that affect the atmosphere, soil and water worldwide (Plakhotnik et al. 2005). Another impact resulting from the construction and establishment of the railways is soil erosion. Here, we describe the main railway disturbances that can potentially affect wildlife.

\section{Noise and Vibration}

Railway noise pollution can be either from airborne sound or from vibration-induced as a result of rail traffic (Czop and Mendrok 2011; Palacin et al. 2014). The main source of railway noise comes from freight wagons, followed by high-speed trains and inner-urban railways (Guarinoni et al. 2012). However, locomotives passing and accelerating, freight wagons braking, vibrations from rail corrugation, and out-of-round wheels or vehicle coupling in shunting yards, are other sources of noise (Clausen et al. 2010). Noise levels vary, depending on the landscape and weather; open and flat areas allow noise to travel further than forest or mountains areas. In mountainou areas, the effect of noise is greater within valleys, when their width is less than the height of their walls, reducing the attenuating effect of noise (Chiocchia et al. 2010). Frost can make the ground hard and impede sound absorption, but fog prevents noise from dissipating.

Noise above $55 \mathrm{~dB}(\mathrm{~A})$, where $\mathrm{dB}(\mathrm{A})$ is a measure that attempts to correct the way the human ear perceives loudness, is considered noise pollution for humans, and the sound values in the range $65-75 \mathrm{~dB}(\mathrm{~A})$ cause stress to the body, leading to arterial hypertension (high blood pressure), cardiovascular disease, and heart attacks (Berglund et al. 1999). In Canada, the sound level of a passing train reaches values up to $85 \mathrm{~dB}(\mathrm{~A})$, but between trains the sound levels drop to $43-53 \mathrm{~dB}(\mathrm{~A})$ (CTA 2015). Measurement campaigns on high speed trains in several European countries over 10 years revealed sound values ranging from 85.5 to $97 \mathrm{~dB}(\mathrm{~A})$ when the train speed was between 250 and $350 \mathrm{~km} / \mathrm{h}$ (Gautier et al. 2008). In Japan, Matsumoto et al. (2005) compared the noise as a function of distance and observed a high noise level of $64 \mathrm{~dB}$ at $200 \mathrm{~m}$ from a railway in the countryside, a value similar to that near residential areas $(65.7 \mathrm{~dB})$. In fact, in Japan, noise can still reach $72 \mathrm{~dB}$ at $50 \mathrm{~m}$ from the track, i.e., higher than the Japanese permissible standards of $70 \mathrm{~dB}(\mathrm{~A})$ (Kanda et al. 2007). 


\section{Air Pollution and Emission}

The emission of gases from traffic constitutes an important source of environmental pollution all over the world (Hofman et al. 2014). These emissions depend mainly on the type of transport and fuel. Potential sources of contaminants associated with railways include diesel exhaust, and the abrasion of brakes, wheels, and rails, as well as dust from the transport of minerals and treated railway ties (Levengood et al. 2015).

The main pollutants emitted from the diesel-powered locomotives are carbon dioxide $\left(\mathrm{CO}_{2}\right)$, methane $\left(\mathrm{CH}_{4}\right)$, carbon monoxide $(\mathrm{CO})$, nitrogen oxides $\left(\mathrm{NO}_{\mathrm{x}}\right)$, nitrous oxide $\left(\mathrm{N}_{2} \mathrm{O}\right)$, sulphur dioxide $\left(\mathrm{SO}_{2}\right)$, non-methane volatile organic compounds (NMVOC), particulate matter (PM) and hydrocarbon (HC) (Plakhotnik et al. 2005; Cheng and Yan 2011). Some studies reported higher levels of $\mathrm{PM}_{10}$ (where the subscript indicates the largest diameter of the particles in microns) and $\mathrm{PM}_{2.5}$ near railways, higher than the standard level allowed (Beychok 2011) for the USA, Europe, and Asia (Park and Ha 2008; Kamani et al. 2014).

A growing number of monitoring studies have used bioindicator plant species as surrogates of air pollution across railways (e.g., Rani et al. 2006; Hofman et al. 2014). For example, Rani et al. (2006) studied the micromorphology of leaf parts of Croton bonplandianum, Cannabis sativa and Calotropis procera along a gradient of distances from the railway and concluded that the number of stomata and epidermal cells were lower near railways than at 4 kilometers away from the railway. However, no statistical tests were used to evaluate the correlation between railway distance and the number of stomata and epidermal cells. To the best of our knowledge, Rybak and Olejniczak (2013) authored the only published study that measured the accumulation of polycyclic aromatic hydrocarbons (PAH) in animal species. Using Agelenids spider webs to collect dust suspended in the air, they concluded that spiders are efficient indicators of PAHs in roads, but not in railway viaducts due to heavier traffic in the former.

\section{Soil Pollution}

With the increase in the human population and vehicles, emissions arising from transportation have become one of the most important sources of heavy metal, PAHs and herbicides in the soil (Malawaka and Wilkomirski 2001; Böjersson et al. 2004). Fuel combustion, vehicular and track material abrasion, and leaked cargo emit particles containing metals that are deposited in the soils, where they can remain for many years due to their low biodegradability (Zhang et al. 2012).

As most products of vehicle emissions are neither biologically nor chemically degraded, they can affect the growth of plants and ecosystems (Chen et al. 2014a, b). In fact, plants and soil organisms are the first recipients of the emission pollutants (Malawaka and Wilkomirski 2001). Ongoing research indicates that plant 
uptake varies among species. For example, leucaena (Leucaena leucocephala), annual meadow grass (Poa annua), and indigofera (Indigofera amblyantha) are known to have high translocation capacity for some metals, such as lead $(\mathrm{Pb})$ and cadmium (Cd), but limited translocation of heavy metals from the roots to the aboveground tissues (Chen et al. 2014a, b), while others show the opposite trend (Ge et al. 2003).

High concentration levels of heavy metals are often found in the vicinity of railways. Wiłkomirski et al. (2011) reported the same concentration of molybdenum (Mo) close to and approximately $2 \mathrm{~km}$ from the railways in Poland. For instance, the concentration of nickel, cadmium, cobalt, and lead in the moss (Pleurozium schreberi) was the same $30 \mathrm{~m}$ from the railway as it was at points near the railways (Mazur et al. 2013). In addition, high concentrations of PAHs were found in the aerial parts of plant species near the railway and up to distances of $30 \mathrm{~m}$ from the railway (Malawaka and Wilkomirski 2001; Wiłkomirski et al. 2011). On railways, in particular, the biodegradation of PAHs and herbicides is extremely low and can persist over decades (Wilkomirski et al. 2012).

\section{Water Pollution}

Infrastructures associated with railways (e.g., leakages of petroleum products from fuel storage tanks) contribute, together with pollutants, to aquatic ecosystems (Schweinsberg et al. 1999; Vo et al. 2015). Levengood et al. (2015) documented high concentrations of PAHs and heavy metals in waterways bisected or bordered by railways. They showed that the PAH concentration was higher downstream than upstream of the railway (Levengood et al. 2015). They also found that phenanthrene and dibenzo $(\mathrm{a}, \mathrm{h})$ anthracene (a PAH element) concentrations at some sites represented a risk to aquatic life, whereas the chromium $(\mathrm{Cr})$ values were still below the levels of concern for aquatic life (Levengood et al. 2015).

Herbicides and pesticides are other sources of water pollution. For herbicides, Schweinsberg et al. (1999) discovered that in Germany before the 1990s, a much higher total amount of these compounds were applied on railway tracks than in agriculture. Recently, Vo et al. (2015) showed that many herbicides applied during the operation of the railway are at concentrations that are lethal to most of the aquatic fauna, particularly fish populations; they indicate that compounds such as Imazapyr or Diuron concentrations can take 6 and 48 months, respectively, to drop below $50 \%$ of their original levels.

\section{Soil Erosion and Changes in Hydrology}

The abrupt change of soil required to establish the railway embankment leads to vegetation loss, compresses the soil, and compromises water drainage (Ferrell and 
Lautala 2010). Thus, soil becomes exposed and subject to an increasing runoff that promotes its erosion (Chen et al. 2015). The erosion of rail embankments can result in a washing out of sediments (Jin et al. 2008) that cause water pollution. Furthermore, Gregorich et al. (1998) noted that soil erosion and deposition alter the biological process of carbon mineralization in soil landscapes, which affects the soil quality and, hence, the vegetation.

Railway construction parallel to streams can result in hydrological disconnections (Pennington et al. 2010) that dry the soils (Blanton and Marcus 2009). Such disconnections can have a significant impact on the ecological function of riparian landscapes by negatively affecting floodplain evolution, riparian ecosystem processes, and associated biodiversity (Snyder et al. 2002). Although urban riparian areas could harbor great diversity of native canopy and shrub species, the richness of native canopy species was lower near railways (Snyder et al. 2002).

\section{Effects of Railway Disturbance on Wildlife}

There is evidence that disturbance from noise, lights, and vibrations associated with the construction and operation of the railway affect some species, and this can occur at various life cycles (van Rooyen 2009; Wiacek et al. 2015). In contrast, other studies suggest that wildlife ignores or adapts to railway disturbances (Ghosh et al. 2010; Mundahl et al. 2013). As observed for roads, the severity of railway disturbance depends on the species' bio-ecological features and on the degree of the disturbance (e.g., Rytwinski and Fahrig 2012). However, little is known about their role in species viability. We now review the main findings on wildlife behaviour responses to railway disturbance.

\section{Insects}

To the best of our knowledge, only the study by Penone et al. (2012) assessed the impact of railways on insects. They studied Tettigoniidae (bush crickets) at railway edges in an urban context (Penone et al. 2012), and found that species richness and abundance was explained by a quadratic effect of train speed (described by a humpbacked curve). This is especially true of mobile species at larger scales than on sedentary species. However, vegetated railway verges had a significant positive effect on most species, suggesting that suitable habitats with appropriate management can overcome the negative effects of disturbance on larger scales (Penone et al. 2012). 


\section{Herpetofauna}

Among vertebrates, amphibians are one of the groups most affected by linear infrastructures (e.g., Fahrig and Rytwinski 2009). Their dependence on aquatic habitats and seasonal migrations make amphibians particularly vulnerable to the negative impacts of these structures (Hels and Buchwald 2001; Hamer and McDonnell 2008). However, to the best of our knowledge no studies have been carried out on the impact of railway disturbances on amphibians.

In contrast, there have been several studies that show that reptiles ignore railway disturbances. For example, in Belgium, all autochthonous reptile species have colonized the railway embankments, but their presence and abundance largely depend on the region and on the kind of railway (Graitson 2006). Railway embankments can provide important novel habitats for reptiles, mainly in highly human-altered landscapes (EN 2004). Some active lines in sunny areas of large valleys and some large switchyards, as well as unused railways not dismounted, had a particularly high richness of reptiles (Graitson 2006). In fact, those railways may have contributed to the local dispersal of at least five species of reptiles: slow worm (Anguis fragilis), sand lizard (Lacerta agilis), common wall lizards (Podarcis muralis), viviparous lizard (Zootoca vivipara), and smooth snake (Coronella austriaca) (Graitson 2006). Likewise, the rainbow lizard (Cnemidophorus lemnistactus) was found in the weeds growing along the Florida East Coast Railway line occupied by industrial buildings (Wilson and Porras 1983). In Switzerland, a relatively great abundance of reptile species can be found in the vicinity of the railways, especially sand lizards (Stoll 2013). However, the abundance of reptiles in the railway banks can be affected by two key factors: the inter-specific competition with the common wall lizard Podarcis muralis, and predation through domestic cats Felis catus (Stoll 2013).

\section{Birds}

There have been several studies that show that railway disturbance affects bird richness, abundance, and behaviour. Noise can affect acoustic communication among bird species that use calls and songs to attract and bond with mates, defend territories from rivals, maintain contact with social groups, beg for food, and warn of danger from approaching predators (Collins 2004; Marler 2004). Noise disturbance was shown to alter the behaviour of many bird species, especially for breeding birds, when territories are being defended, and during incubation (Reijnen et al. 1995). This disturbance can cause birds to accelerate hatching, abandon their occupied territories, nests and broods, and lead to hearing loss (Hanson 2007).

For example, noise emission from railway traffic has a negative effect on the density of all meadow birds in the Netherlands (Waterman et al. 2002). The threshold noise level from which densities were affected was around 42-49 dB(A) 
for the black-tailed godwit (Limosa limosa), skylark (Alauda arvensis), and garganey (Anas querquedula) (Waterman et al. 2002). There was also evidence that successful bald eagle (Haliaeetus leucocephalus) nests were farther away from highways and railways than unsuccessful ones (Mundahl et al. 2013).

Certain bird species seem to ignore railway disturbances. For example, brants (Branta asp.) seem to disregard the trains passing $50 \mathrm{~m}$ away (Owens 1977). Likewise, although Waterman et al. (2002) found a negative effect on the density of birds on railways in general, they did not find differences in bird density between quiet and busy railways. Indeed, there is evidence that bird species tolerate the railway disturbance due to the attractiveness of numerous railway-related features. Species whose predators show negative responses to train disturbance may also benefit from the railway vicinity (Rytwinski and Fahrig 2012). Railway verges may create edge effects that can increase biodiversity. In fact, special microclimatesthanks to different temperatures or insolation and new habitat availability along the edges - can enhance habitat heterogeneity in homogeneous landscapes (Delgado et al. 2007). In turn, these new habitats may improve resting and foraging opportunities for some bird species (Morelli et al. 2014). Also, railways can be a useful source for gastroliths' digestive purposes, and a source of sand bathing locations used by birds to clean the feathers. Ghosh et al. (2010) showed that apparently due to the food availability, house sparrows (Passer domesticus) adapted to loud noise (between 35 and $95 \mathrm{~dB}$ ), being undisturbed by passing trains at the railway station study site. Equally, Li et al. (2010) observed the abundance and richness of seven ground-dwelling bird species, namely the Tibetan ground tit (Pseudopodoces humilis), Tibetan lark (Melanocorypha maxima), horned lark (Eremophila alpestris), white-winged snowfinch (Montifringillla nivalis), plain-backed snowfinch ( $M$. blandfordi), white-rumped snowfinch (M. taczanowskii), and rufous-necked snowfinch (M. ruficollis). They found greater numbers of individuals of these species near the Qinghai-Tibet railway (less than $300 \mathrm{~m}$ ) than farther away (from 300 to $1,200 \mathrm{~m}$ ), probably due to verges provide nesting sites and foraging opportunities.

The non-continuous nature of the noise near railways due to the intermittent flow of train traffic may constitute the main reason that some birds ignore the railway. This was hypothesized by Wiacek et al. (2015) to explain the greater abundance of the breeding community of woodland birds near a busy railway line in Poland when they assessed the effect of noise at three different distances from the track (30, 280, and $530 \mathrm{~m})$. Species with low frequency calls, such as the wood pigeon (Columba palumbus) and common cuckoo (Cuculus canorus), also occurred in large numbers near railways. Other bird species also seem to ignore the railway disturbance. For example, more than $90 \%$ of bald eagle nests were built near human infrastructures, including railways that had more than 1,000 railcars going by each day (Mundahl et al. 2013). 


\section{Mammals}

Railway disturbance impacts differ among mammal species. Besides the higher intensity of light and noise (it can achieve $120 \mathrm{~dB}$ ), small mammals can be found near the railways if there is no grazing disturbance (Qian et al. 2009), or if the unnatural nature of rail bed and tracks is not an obstacle to their movements (van der Grift 1999). In fact, the richness of small mammal species was high at the railway verge in the Atlantic forest in southern Brazil (Cerboncini 2012), probably because the noise from the trains can force predators out of the area, which can favor small mammals' appearance (Cerboncini 2012). Similarly, railways may have a positive role in maintaining the common bat populations in highly humanized landscapes, such as intensive agriculture. In this case, railway verges seem to be used as shelters for bat species despite the traffic noise; only Myotis sp. foraging behaviour was negatively affected by railway verges (Vandevelde et al. 2014).

Although the response of large mammals to the effects of railway disturbance varies among species, they seem to ignore railway disturbances. However, there is evidence that the presence of railways had a subtle effect on some species' behaviour. For example, railways had little effect on the distance or direction of fox dispersal movements (Trewhella and Harris 1990); however, the railway disturbance may have influenced the fox movements within their territories (Trewhella and Harris 1990). Similarly, the Canadian Pacific Railway in Banff National Park seems to redirect wolf movements (individuals follow the railway), particularly when the snow is deep (Paquet and Callaghan 1996), while it seems to define the boundary of bears' home ranges (Kaczensky et al. 2003). As detected for other species groups, changes in the railway verges can attract large mammals. In Banff National Park, railway verges attracted black and grizzly bears (Ursus americanus and U. arctos, respectively) due to the berry-producing areas within the verges (Gibeau and Herrero 1998). Grain spills along the Canadian Pacific rail line also attract bears (Gibeau and Herrero 1998), while food spills seem to increase the abundance of mice, which may attract their predators, such as the coyote (Wells 1996).

By contrast, railways seem to be avoided by two large ungulates: Mongolian gazelles (Procopra gutturosa) and Tibetan antelopes (Pantholops hodgsoni). No observations of Mongolian gazelle crossings during dispersal were detected, and most of the individuals were found $300 \mathrm{~m}$ from the railway (Ito et al. 2005). Likewise, there were no Tibetan antelope crossings (Xia et al. 2007) because these antelopes hesitated to cross the railway, most likely because of the slope of the rail bed.

\section{Mitigation Measures to Reduce Railway Disturbances}

There are several measures to reduce the main negative effects of railway disturbances (Schulte-Werning et al. 2008; Maeda et al. 2012; Nielsen et al. 2015). Although some of these measures are known to effectively reduce the major 
negative effects on biodiversity, the effectiveness has not yet been evaluated for a few other measures. Here, we describe the commonly used measures to reduce or minimize the impacts of railway disturbance for noise and vibration effects, and soil pollution and erosion that are found in the literature.

\section{Noise and Vibration}

In general, there are two approaches to minimizing rail traffic noise and vibration: (1) reduce the noise at the source, and (2) reduce its propagation (Lakušić and Ahac 2012; Tiwari et al. 2013). The reduction of noise levels can be achieved by decreasing the speed of rail vehicles and reducing the intensity of the radiated sound through regular maintenance in order to keep smooth rails and wheels (Lakušić and Ahac 2012; Schulte-Werning et al. 2012). Currently, rail fastenings, rail dampers, under-sleeper pads, and noise barriers (Fig. 6.1) are the most commonly used techniques to directly reduce the noise and vibration in railways, techniques that are also used in roads and motorways. The increased flexibility of railway elements (e.g., fastenings, sleepers, ballasts), have increased their ability to absorb vibrations generated at wheel-rail interface (Lakušić and Ahac 2012). The use of resilient rail fastening systems are designed to decrease the low-frequency ground borne or in structures with noise above $30 \mathrm{~Hz}$ and can be effective in reducing wayside noise

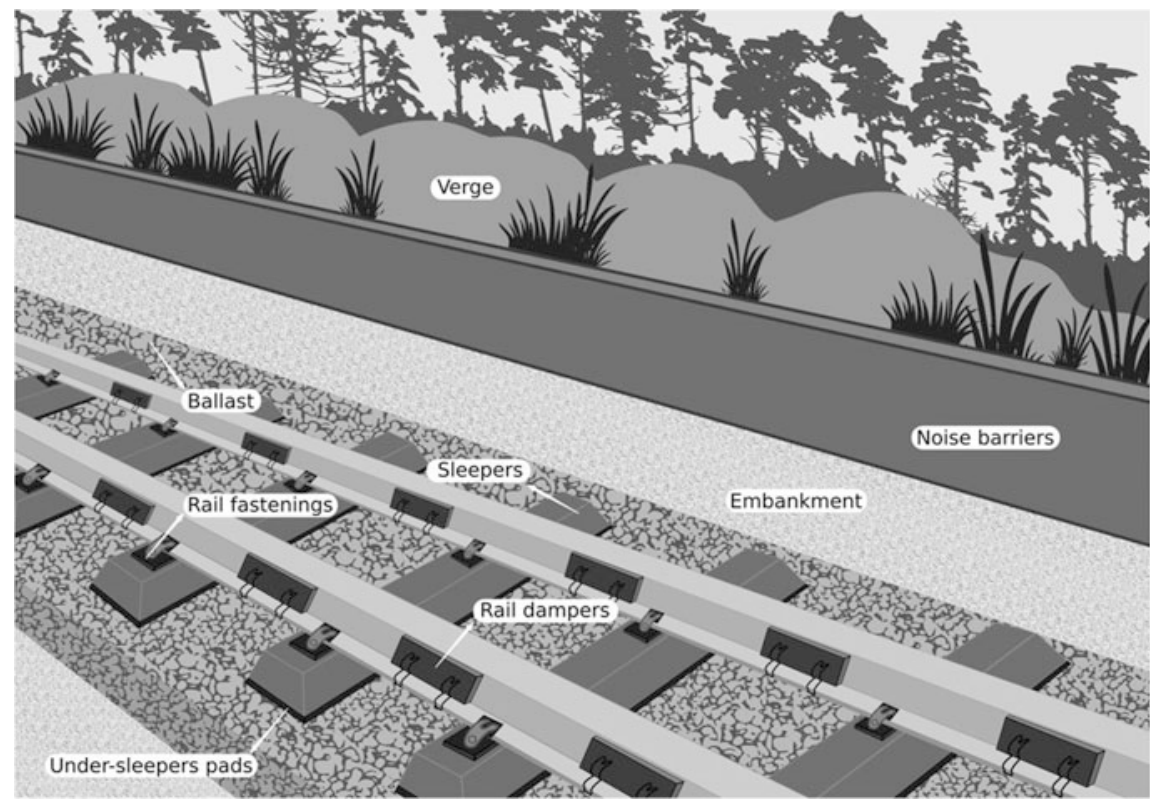

Fig. 6.1 Schematic drawing of a railway showing some measures to minimize noise and vibration: rail fastenings; rail dampers; under-sleepers pads; and noise barriers (not at scale) 
radiated from steel. This structure provides noise reduction from 3 to $6 \mathrm{~dB}(\mathrm{~A})$ through the elastic elements supporting the rail, which prevents direct contact between the rail foot and sleeper (Nelson 1997). However, systems that use concrete ties with spring clips may not benefit from the use of resilient fasteners, because the spring clips already eliminate any looseness between the rail and the tie (Nelson 1997).

Another technique is the use of rail dampers (Fig. 6.1). This structure consists of steel components and elastomeric material that absorbs the energy of rail (springs) vibrations (Lakušić and Ahac 2012). The damping material reduces the displacement of the vibration waves along the rail, which results in the reduction of the rail noise. Dampers are known to be an efficient way to reduce noise emission in railway networks (Lakušić and Ahac 2012). Studies performed at the rail track sections with rail dampers installed showed a reduction in noise from 4 to $6 \mathrm{~dB}(\mathrm{~A})$, and vibration up to $9 \mathrm{~dB}$ (Benton 2006; Koller et al. 2012).

Aside from rail noise, non-audible vibrations are also generated by the trains, transmitted via the tracks, and transferred to the soil. In surface railway lines, sleepers with elastic supports (under-sleeper pads-USPs) (Fig. 6.1) are an alternative with moderate costs (compared to floating slab track systems and ballast mats) that increase track quality and achieve a significant reduction in vibrations and railway noise (Schulte-Werning et al. 2012). USPs are resilient pads attached to the bottom surface of sleepers to provide an intermediate elastic layer between the sleeper and the ballast. The USPs are normally made of polyurethane elastomer with a foam structure that includes encapsulated air voids (Johansson et al. 2008). The use of USPs causes an average reduction of vibration of $16 \mathrm{~dB}$ due to the reduction of the contact between the sleeper and the ballast, which increases elasticity of the track (Lakušic et al. 2010; Lakušić and Ahac 2012).

Commonly used to isolate the noise on railways (and roads), noise barriers (Fig. 6.1) can be an important tool for minimizing the negative effects of sound on wildlife, especially for species that are extremely sensitive to it. These structures can be constructed from soil, wood, concrete, or metal (FHWA 2011; Morgan and Peeling 2012), or can be just the dense vegetation along the rails, which can, in some cases, form an almost perfect noise barrier (Tiwari et al. 2013; Bashir et al. 2015). Soil verges along roads and railways can reduce, on average, $3 \mathrm{~dB}$ more than vertical walls of the same height. However, the construction of soil verges can require a huge area, especially if they are very extensive and elevated. The construction of artificial walls requires less space, but they are usually limited to eight meters in height for structural and aesthetic reasons (FHWA 2011). Vertical walls can be applied, together with soil verges, in order to further reduce noise.

Studies by Van Renterghem and Botteldooren (2012) show that a soil verge can reduce, on average, noise levels of $11.1 \mathrm{~dB}$, and walls can reduce, on average 7.7$8.3 \mathrm{~dB}$. According to the U.S. Department of Transportation, effective noise barriers can typically reduce noise levels by $5-10 \mathrm{~dB}$ (FHWA 2011). Noise barriers have been mainly used to reduce the effect of noise on colonies of nesting birds (Bank et al. 2002). However, when applied without planning, noise barriers can cause various negative impacts on wildlife, such as the isolation of populations 
(Bank et al. 2002). Thus, it is recommended to apply noise barriers together with wildlife passages to promote crossings between railway sides in order to maintain dispersal processes and ensure the long-term persistence of the species (Bank et al. 2002; Schulte-Werning et al. 2012). However, reducing the noise disturbance may reduce the ability of wildlife to perceive incoming trains, and consequently increase the risk of collision (see Chap. 2).

\section{Soil Pollution}

Cleaning the ballast using ethylenediaminetetraacetate (EDTA) with water or thermosetting plastic resin are techniques that allow the recycling of pollutant components in the surroundings of the railway network. Cleaning it can typically involve the use of products such as solvents or surfactants, which vary in efficiency and potential environmental impacts (Anderson et al. 2002). The ballast cleaning technology with aqueous solutions of disodium EDTA can ensure metal extraction without altering the stones' mechanical and physical characteristics, allowing reuse of the ballast (Di Palma and Petrucci 2015). The use of EDTA offers a high extraction efficiency of heavy metals (Di Palma et al. 2011); however, this chemical agent should be administered with caution because it has low biodegradability in the environment (Bucheli-Witschel and Egli 2001).

Using water to extract the ballast pollutants is very common in many countries (Di Palma et al. 2012). However, this method requires a great amount of surfactant water, and the disposal of the waste produced after cleaning must be treated appropriately (Cho et al. 2008). Incineration, landfilling, or recycling of the waste are the options available, with the choice depending on the solvent system and on the nature of the waste (Anderson et al. 2002). Dry cleaning that uses thermosetting plastic resin can successfully remove ballast pollutants in a very short time (Cho et al. 2008). In areas with high levels of contamination, the support material should be renovated regularly, including changing the ballast, and wood sleepers should be replaced by concrete (Wiłkomirski et al. 2011).

\section{Soil Erosion}

There are techniques commonly used to minimize the effects of soil erosion on railways and highways: grass plantation, use of gypsum, application of compost/mulch coverage, use of concrete prefabricated panes, lattice plots, and interception and drainage. There is evidence that as the grass cover level increases, the soil erosion rate decreases (Gyasi-Agyei et al. 2001). For example, buffel grass (Cenchrus ciliaris) is one of the preferred species for revegetation of railway embankments in Australia (Bhattarai et al. 2008); in some of the areas (Central Australia and Western Queensland), this grass spreads readily in soils with crumbly 


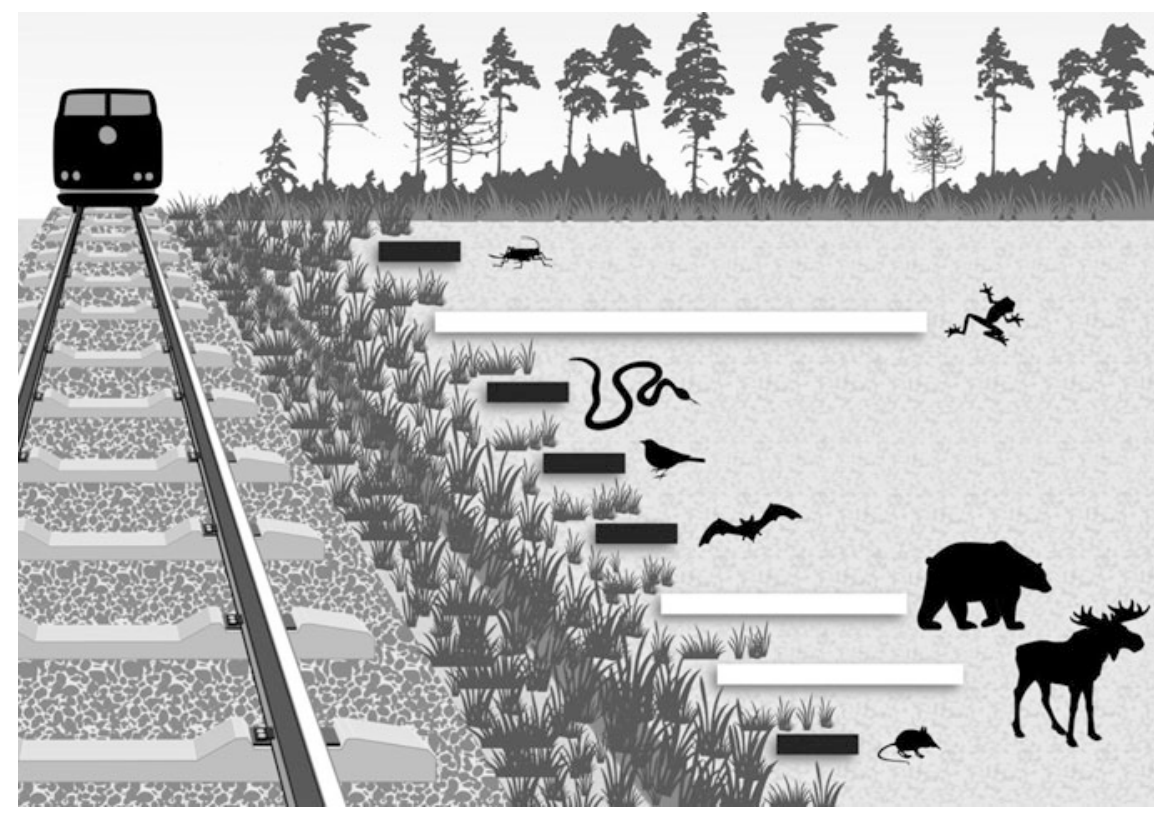

Fig. 6.2 Spatial responses of wildlife to railway disturbances: the length of the white bars are proportional to the distances up to which the railway has an effect on a given taxon, while short and black bars correspond to species' occurrence in the railway verges

or soft surfaces, but it needs to be handled with care because it has the potential to become a weed (Cameron 2004). This species, in combination with Japanese millet (Echinochloa esculenta), has also been used successfully in controlling soil erosion in the semi-arid tropics of Central Queensland. Japanese millet develop rapidly in poor soils and can minimize the invasion of other unwanted weed species (Fox et al. 2010). However, buffel grass is an invasive weed species that poses serious threats to biodiversity in many other environments, such as in the Australian regions mentioned above (Marshall et al. 2012) (see Chap. 4).

The use of gypsum on calcium-deficient soil before seeding can reduce the erosion rate by $25 \%$ (Gyasi-Agyei et al. 2001). This material has advantages, such as low cost, availability, $\mathrm{pH}$ neutrality, and ease of handling (Gyasi-Agyei et al. 2001). Once applied to the soil, the gypsum will increase the porosity and water infiltration ability. This phenomenon will avoid water runoff, thus preventing soil erosion (Beckett et al. 1989). The use of this mineral also promotes root penetration and the emergence of seedlings (Chen and Dick 2011).

Compost/mulch coverage is considered to be one of the best management practices in both active construction and established areas prone to soil erosion on roadsides (Bakr et al. 2012), and it can be used in railway verges as well. In Louisiana, USA, Bakr et al. (2012) found that compost/mulch covers were highly effective in reducing runoff, total suspended solids (reduction between 70 and 
$74 \%$ ), and turbidity from soils susceptible to high-intensity storms. A study performed by Persyn et al. (2004) showed that the use of various compounds applied to the soil might also reduce erosion rates. All compost treatments (biosolids, yard waste, and bio-industrial by-products) were effective at reducing runoff and inter-rill erosion rates under the conditions simulated in the study conducted on a highway embankment after construction in central Iowa (Persyn et al. 2004).

There are also engineering measures, such as concrete prefabricated panes, geocells (three-dimensional honeycomb-like structures to reduce runoff and sediment transport), or interception and drainage that can also reduce the soil loss along highways and railways (e.g., Xu et al. 2006). These measures were effective in the short term by decreasing between 40 and $60 \%$ of the runoff that had effectively reduced soil loss from sideslopes of highways in the Tibetan Plateau (Xu et al. 2006). However, this measure needs to be applied with some caution, since weak construction may lead to water leaking from improperly sealed cracks or holes, loose contact parts, poorly rammed structures, or runoff converging along a flow line, causing adverse effects on the road embankment and in the surrounding environment (Xu et al. 2006).

\section{Conclusions}

There have been several studies that quantified the level of various disturbances and their impacts on wildlife populations. Plants are, in general, the first to be described in relation to air and soil contamination, perhaps due to the facility of realizing experimental analysis, or of using plants as bio-indicators. Nevertheless, there is still little scant knowledge about the mechanisms and processes underlying the behaviour of vertebrates, because most studies concerned only a small number of species (van der Grift 1999). There is strong evidence that noise, light, and vibrations that can reach from 85.5 to $97 \mathrm{~dB}(\mathrm{~A})$, can affect insects, amphibians and birds (Fig. 6.2). In contrast, the availability of food and vegetation in the railway verges seems to overcome the noise pollution and seems to attract reptiles, some bird species, and several mammals (Fig. 6.2). There is a wide diversity of measures to minimize railway disturbances, but further studies are needed to understand the effectiveness of these measures in reducing railway disturbance of wildlife.

Acknowledgments This research for this chapter was conducted within the framework of the project "Road macroecology: analysis tools to assess impacts on biodiversity and landscape structure," that was funded by CNPq in Brazil (No 401171/2014-0). CG was supported by the Grant (300021/2015-1). 


\section{References}

Anderson, P., Cunningham, C. J., \& Barry, D. A. (2002). Efficiency and potential environmental impacts of different cleaning agents used on contaminated railway ballast. Land Contamination \& Reclamation, 10, 71-78.

Bakr, N., Weindorf, D. C., Zhu, Y., Arceneaux, A. E., \& Selim, H. M. (2012). Evaluation of compost/mulch as highway embankment erosion control in Louisiana at the plot-scale. Journal of Hydrology, 468, 257-267.

Bank, F. G., Irwin, C. L., Evink, G. L., Gray, M. E., Hagood, S., Kinar, J. R., et al. (2002). Wildlife habitat connectivity across European highways (No. FHWA-PL-02-011).

Bashir, I., Taherzadeh, S., Shin, H. C., \& Attenborough, K. (2015). Sound propagation over soft ground without and with crops and potential for surface transport noise attenuation. The Journal of the Acoustical Society of America, 137, 154-164.

Beckett, P. H. T., Bouma, J., Farina, M. P. W., Fey, M. V., Miller, W. P., Pavan, M. A., et al. (1989). Advances in soil science (p. 9). New York: Springer.

Benton, D. (2006). Engineering aspects of rail damper design and installation. Rail Noise 2006: Mitigazione del Rumore Ferroviario, GAA, Arpat news, Pisa, 179.

Berglund, B., Lindvall, T., \& Schwela, D. H. (1999). Guidelines for community noise. World Health Organization. Retrieved February 3, 2016, from http://www.who.int/docstore/peh/ noise/guidelines2.html

Beychok, M. (2011). U. S. National ambient air quality standards. Retrieved February 3, 2016, from http://www.eoearth.org/view/article/170853/

Bhattarai, S. P., Fox, J., \& Gyasi-Agyei, Y. (2008). Enhancing buffel grass seed germination by acid treatment for rapid vegetation establishment on railway batters. Journal of Arid Environments, 72, 255-262.

Blanton, P., \& Marcus, W. A. (2009). Railroads, roads and lateral disconnection in the river landscapes of the continental United States. Geomorphology, 112, 212-227.

Böjersson, E., Lennart, T., \& Stenström, J. (2004). The fate of imazapyr in a Swedish railway embankment. Pest Management Science, 60, 544-549.

Bucheli-Witschel, M., \& Egli, T. (2001). Environmental fate and microbial degradation of aminopolycarboxylic acids. FEMS Microbiology Reviews, 25, 69-106.

Cameron, A. G. (2004). Buffel grass (A pasture grass for sandy soils) (online). Northern Territory Government, Australia. Retrieved February 9, 2016, from http://www.nt.gov.au/d/Content/ File/p/Pasture/283.pdf

Cerboncini, R. (2012). Respostas de pequenos mamíferos ao efeito de borda da ferrovia Paranaguá-Curitiba no parque estadual pico do marumbi, morretes. Dissertation. University of Paraná.

Chen, L., \& Dick, W. A. (2011). Gypsum as an agricultural amendment: General use guidelines. Ohio State University Extension.

Chen, Z., Ai, Y., Fang, C., Wang, K., Li, W., Liu, S., et al. (2014b). Distribution and phytoavailability of heavy metal chemical fractions in artificial soil on rock cut slopes alongside railways. Journal of Hazardous Materials, 273, 165-173.

Chen, Z., Luo, R., Huang, Z., Tu, W., Chen, J., Li, W., et al. (2015). Effects of different backfill soils on artificial soil quality for cut slope revegetation: Soil structure, soil erosion, moisture retention and soil C stock. Ecological Engineering, 83, 5-12.

Chen, Z., Wang, K., Ai, Y., Li, W., Gao, H., \& Fang, C. (2014a). The effects of railway transportation on the enrichment of heavy metals in the artificial soil on railway cut slopes. Environmental Monitoring and Assessment, 186, 1039-1049.

Cheng, Y. H., \& Yan, J. W. (2011). Comparisons of particulate matter, $\mathrm{CO}$, and $\mathrm{CO}_{2}$ levels in underground and ground-level stations in the Taipei mass rapid transit system. Atmospheric Environment, 45, 4882-4891.

Chiocchia, G., Clerico, M., Salizzoni, P., \& Marro, M. (2010). Impact assessment of a railway noise in an alpine valley. In 10ème Congrès Français d'Acoustique. 
Cho, Y., Park, D. S., Lee, J. Y., Yung, W. S., Kim, H. M., \& Lim, J. I. (2008). Dry cleaning of railroad ballast gravels by blasting with thermosetting plastic resin powder. In Proceedings of 8th World Congress on Railway Research, Coex, Seoul, Korea (pp. 18-22).

Clausen, U., Doll, C., Franklin, F. J., Heinrichmeyer, H., Kochsiek, J., Rothengatter, W., et al. (2010). Reducing railway noise pollution. Directorate General for Internal Policies, Policy Department B: Structural and cohesion policies. Transport and Tourism, European Parliament.

Clauzel, C., Girardet, X., \& Foltête, J. C. (2013). Impact assessment of a high-speed railway line on species distribution: Application to the European tree frog (Hyla arborea) in Franche-Comté. Journal of Environmental Management, 127, 125-134.

Collins, S. (2004). Vocal fighting and flirting: The functions of birdsong. In P. Marler \& H. Slabbekoorn (Eds.), Nature's music: The science of birdsong (pp. 39-79). San Diego, California: Academic/Elsevier.

CTA. (2015). Railway noise measurement and reporting methodology. Retrieved February 3, 2016, from https://www.otc-cta.gc.ca/eng/railway_noise_measurement

Czop, P., \& Mendrok, K. (2011). A new method for operational monitoring of railway tracks to reduce environmental noise. Polish Journal of Environmental Studies, 20, 311-316.

Delgado, J. D., Arroyo, N. L., Arevalo, J. R., \& Fernandez-Palacios, J. (2007). Edge effect of roads on temperature, light, canopy cover, and canopy height in laurel and pine forests. Landscape and Urban Planning, 81, 328-340.

Di Palma, L., Gonzini, O., \& Mecozzi, R. (2011). Use of different chelating agents for heavy metal extraction from contaminated harbour sediment. Chemistry and Ecology, 27, 97-106.

Di Palma, L., Mancini, D., \& Petrucci, E. (2012). Experimental assessment of chromium mobilization from polluted soil by washing. Chemical Engineering Transactions, 28, 145-150.

Di Palma, L., \& Petrucci, E. (2015). Treatment and recovery of contaminated railway ballast. Turkish Journal of Engineering and Environmental Sciences, 38, 248-255.

Eigenbrod, F., Hecnar, S. J., \& Fahrig, L. (2009). Quantifying the road effect zone: Threshold effects of a motorway on anuran populations in Ontario, Canada. Ecology and Society, 14, 18 24.

EN. (2004). Reptiles: Guidelines for developers. English Nature. Northampton: Belmont Press.

Fahrig, L., \& Rytwinski, T. (2009). Effects of roads on animal abundance: An empirical review and synthesis. Ecology and Society, 14, 21.

Ferrell, S. M., \& Lautala, P. T. (2010). Rail embankment stabilization on permafrost. London: Global Experiences.

FHWA, Federal Highway Administration. (2011). Highway traffic noise barriers at a glance. Washington, DC: U. S. Department of Transportation.

Forman, R. T., \& Alexander, L. E. (1998). Roads and their major ecological effects. Annual Review of Ecology and Systematics, 207-C2.

Fox, J. L., Bhattarai, S. P., \& Gyasi-Agyei, Y. (2010). Evaluation of different seed mixtures for grass establishment to mitigate soil erosion on steep slopes of railway batters. Journal of Irrigation and Drainage Engineering, 137, 624-631.

Gautier, P. E., Poisson, F., \& Letourneaux, F. (2008). High speed trains external noise: A review of measurements and source models for the TGV case up to $360 \mathrm{~km} / \mathrm{h}$. In Proceedings of the 8th world congress on railway research (pp. 1-1).

Ge, Y., Murray, P., Sauvé, S., \& Hendershot, W. (2003). Low metal bioavailability in a contaminated urban site. Environmental Toxicology and Chemistry, 21, 954-961.

Gibeau, M. L., \& Herrero, S. (1998). Roads, rails, and grizzly bears in the Bow River Valley, Alberta. In G. L. Evink (Ed.), Proceedings of the international conference on ecology and transportation (pp. 104-108), Florida Dept. of Transportation, Tallahassee, Florida, USA.

Graitson, E. (2006). Répartition et écologie des reptiles sur le réseau ferroviaire en Wallonie. Bulletin de la Societe Herpetologique, 120, 15-32.

Gregorich, E. G., Greer, K. L., Anderson, D. W., \& Liang, B. C. (1998). Carbon distribution and losses: Erosion and deposition effects. Soil and Tillage Research, 47, 291-302.

Ghosh, S., Kim, K., \& Bhattacharya, R. (2010). A survey on house sparrow population decline at Bandel, West Bengal, India. Journal Korean Earth Science Society, 31, 448-453. 
Guarinoni, M., Ganzleben, C., Murphy, E., \& Jurkiewicz, K. (2012). Towards a comprehensive noise strategy. Brussels: European Union.

Gyasi-Agyei, Y., Sibley, J., \& Ashwath, N. (2001). Quantitative evaluation of strategies for erosion control on a railway embankment batter. Hydrological Processes, 15, 3249-3268.

Hamer, A. J., \& McDonnell, M. J. (2008). Amphibian ecology and conservation in the urbanising world: A review. Biological Conservation, 141, 2432-2449.

Hanson, C. E. (2007). High speed train noise effects on wildlife and domestic livestock. In B. S. Werning, D. Thompson, P. E. Gautier, C. Hanson, B. Hemsworth, J. Nelson, T. Maeda, \& P. Vos (Eds.), Noise and vibration mitigation for rail transportation systems (pp. 26-32). New York: Springer.

Hels, T., \& Buchwald, E. (2001). The effect of road kills on amphibian populations. Biological Conservation, 99, 331-340.

Hofman, J., Lefebvre, W., Janssen, S., Nackaerts, R., Nuyts, S., Mattheyses, L., et al. (2014). Increasing the spatial resolution of air quality assessments in urban areas: A comparison of biomagnetic monitoring and urban scale modelling. Atmospheric Environment, 92, 130-140.

Ito, T., Miura, N., Lhagvasuren, B., Enkhbileg, D., Takatsuki, S., Tsunekawa, A., et al. (2005). Preliminary evidence of a barrier effect of a railroad on the migration of Mongolian gazelles. Conservation Biology, 19, 945-948.

Jin, H. J., Yu, Q. H., Wang, S. L., \& Lü, L. Z. (2008). Changes in permafrost environments along the Qinghai-Tibet engineering corridor induced by anthropogenic activities and climate warming. Cold Regions Science and Technology, 53, 317-333.

Johansson, A., Nielsen, J. C., Bolmsvik, R., Karlström, A., \& Lundén, R. (2008). Under sleeper pads-Influence on dynamic train-track interaction. Wear, 265, 1479-1487.

Kaczensky, P., Knauer, F., Krze, B., Jonozovic, M., Adamic, M., \& Gossow, H. (2003). The impact of high speed, high volume traffic axes on brown bears in Slovenia. Biological Conservation, 111, 191-204.

Kamani, H., Hoseini, M., Seyedsalehi, M., Mahdavi, Y., Jaafari, J., \& Safari, G. H. (2014). Concentration and characterization of airbone particles in Tehran's subways system. Environmental Science and Pollution Research, 21, 7319-7328.

Kanda, H., Tsuda, H., Ichikawa, K., \& Yoshida, S. (2007). Environmental noise reduction of Tokaido Shinkansen and future prospect. In B. S. Werning, D. Thompson, P. E. Gautier, C. Hanson, B. Hemsworth, J. Nelson, T. Maeda, \& P. Vos (Eds.), Noise and vibration mitigation for rail transportation systems (pp. 1-8). Berlin, Heidelberg: Springer.

Koller, G., Kalivoda, M. T., Jaksch, M., Muncke, M., Oguchi, T., \& Matsuda, Y. (2012). Railway noise reduction technology using a damping material. In T. Maeda, P. E. Gautier, C. Hanson, B. Hemsworth, J. T. Nelson, B. Schulte-Werning, D. Thompson, \& P. Vos (Eds.), Noise and vibration mitigation for rail transportation systems (pp. 159-166). Tokyo: Springer.

Lakušić, S., \& Ahac, M. (2012). Rail traffic noise and vibration mitigation measures in urban areas. Technical Gazette, 19, 427-435.

Lakušić, S., Ahac, M., \& Haladin, I. (2010). Experimental investigation of railway track with under sleeper pad. In: 10th Slovenian road and transportation congress (pp. 386-393). Vilhar Matija (ur.). Ljubljana.

Levengood, J. M., Heske, E. J., Wilkins, P. M., \& Scott, J. W. (2015). Polyaromatic hydrocarbons and elements in sediments associated with a suburban railway. Environmental Monitoring and Assessment, 187, 1-12.

Li, Z., Ge, C., Li, J., Li, Y., Xu, A., Zhou, K., et al. (2010). Ground-dwelling birds near the Qinghai-Tibet highway and railway. Transportation Research Part D, 15, 525-528.

Maeda, T., Gautier, P. E., Hanson, C., Hemsworth, B., Nelson, J. T., Schulte-Werning, B., et al. (2012). Noise and vibration mitigation for rail Transportation systems. In Notes on numerical fluid mechanics and multidisciplinary design (Vol. 118).

Malawaka, M., \& Wilkomirski, B. (2001). An analysis of soil and plant (Taraxacum officinale) contamination with heavy metals and polycyclic aromatic hydrocarbons (PAHs) in the area of the railway junction IŁAWA GŁÓWNA, Poland. Water, Air, and Soil Pollution, 127, 339349. 
Marler, P. (2004). Bird calls: A cornucopia for communication. In P. Marler \& H. Slabbekoorn (Eds.), Nature's music: The science of birdsong (pp. 132-177). San Diego, California: Academic/Elsevier.

Marshall, V. M., Lewis, M. M., \& Ostendorf, B. (2012). Buffel grass (Cenchrus ciliaris) as an invader and threat to biodiversity in arid environments: A review. Journal of Arid Environments, 78, 1-12.

Matsumoto, S., Shao, X., \& Shino, K. (2005). Environmental noise in Middle East region of Kochi Prefecture [Japan]. Transactions of the Japanese Society of Irrigation, Drainage and Reclamation Engineering (Japan).

Mazur, Z., Radziemska, M., Maczuga, O., \& Makuch, A. (2013). Heavy metal concentrations in soil and moss (Pleurozium schreberi) near railroad lines in Olsztyn (Poland). Fresenius Environmental Bulletin, 22, 955-961.

Morelli, F., Beim, M., Jerzak, L., Jones, D., \& Tryjanowski, P. (2014). Can roads, railways and related structures have positive effects on birds? A review. Transportation Research Part D, $30,21-31$.

Morgan, P. A., \& Peeling, J. (2012). Railway noise mitigation factsheet 01: Overview of railway noise. HS2 Rail Project Group.

Mundahl, N. D., Bilyeu, A. G., \& Maas, L. (2013). Bald Eagle nesting habitats in the Upper Mississippi River National Wildlife and Fish Refuge. Journal of Fish and Wildlife Management, 4, 362-376.

Nelson, J. T. (1997). Wheel/rail noise, control manual (No. Project C-3 FY'93), Washington, DC.

Nielsen, J., Anderson, D. F., Gautier, P.-E., Iida, M., Nelson, J. T., Thompson, D., et al. (2015). Noise and vibration mitigation for rail transportation systems. In Notes on numerical fluid mechanics and multidisciplinary design (Vol. 126).

Owens, N. W. (1977). Responses of wintering brent geese to human disturbance. Wildfowl, 28, 514.

Palacin, R., Correia, J., Zdziech, M., Cassese, T., \& Chitakova, T. (2014). Rail environmental impact: Energy consumption and noise pollution assessment of different transport modes connecting Big Ben (London, UK) and Eiffel Tower (Paris, Fr). Transport Problems: An International Scientific Journal, 9.

Paquet, P., \& Callaghan, C. (1996). Effects of linear developments on winter movements of gray wolves in the Bow river Valley of Banff National Park, Alberta. In G. L. Evink, P. Garrett, D. Zeigler, \& J. Berry (Eds.), Trends in addressing transportation related wildlife mortality (pp. 21). Proceedings of the Transportation Related Wildlife Mortality Seminar, Orlando, Florida.

Park, D. U., \& Ha, K. C. (2008). Characteristics of $\mathrm{PM}_{10}, \mathrm{PM}_{2.5}, \mathrm{CO}_{2}$ and $\mathrm{CO}$ monitored in interiors and platforms of subway train in Seoul, Korea. Environment International, 34, 629634.

Pennington, D. N., Hansel, J. R., \& Gorchov, D. L. (2010). Urbanization and riparian forest woody communities: Diversity, composition, and structure within a metropolitan landscape. Biological Conservation, 143, 182-194.

Penone, C., Kerbiriou, C., Julien, J. F., Julliard, R., Machon, N., \& Viol, I. (2012). Urbanisation effect on orthoptera: Which scale matters? Insect Conservation and Diversity, 6, 319-327.

Persyn, R. A., Glanville, T. D., Richard, T. L., Laflen, J. M., \& Dixon, P. M. (2004). Environmental effects of applying composted organics to new highway embankments: Part 1. interrill runoff and erosion. Transactions of the American Society of Agricultural Engineers, 47, 463-469.

Plakhotnik, V. N., Onyshchenko, J. V., \& Yaryshkina, L. A. (2005). The environmental impacts of railway transportation in the Ukraine. Transportation Research D, 10, 263-268.

Qian, Z., Lin, X., Jun, M., Pan-Wen, W., \& Qi-Sen, Y. (2009). Effects of the Qinghai-Tibet Railway on the community structure of rodents in Qaidam desert region. Acta Ecologica Sinica, 29, 267-271.

Rani, M., Pal, N., \& Sharma, R. K. (2006). Effect of railway engines emission on the micromorphology of some field plants. Journal of Environmental Biology, 27, 373-376. 
Reijnen, R., Foppen, R., Braak, C. T., \& Thissen, J. (1995). The effects of car traffic on breeding bird populations in woodland. III. Reduction of density in relation to the proximity of main roads. Journal of Applied Ecology, 32, 187-202.

Rybak, J., \& Olejniczak, T. (2013). Accumulation of polycyclic aromatic hydrocarbons (PAHs) on the spider webs in the vicinity of road traffic emissions. Environmental Science and Pollution Research, 21, 2313-2324.

Rytwinski, T., \& Fahrig, L. (2012). Do species life history traits explain population responses to roads? A meta-analysis. Biological Conservation, 147, 87-98.

Schulte-Werning, B., Asmussen, B., Befr, W., Degen, K. G., \& Garburg, R. (2012). Advancements in noise and vibration abatement to support the noise reduction strategy of Deutsche Bahn. In T. Maeda, P. E. Gautier, C. Hanson, B. Hemsworth, J. T. Nelson, B. Schulte-Werning, D. Thompson, \& P. Vos (Eds.), Noise and vibration mitigation for rail transportation systems (pp. 9-16). New York: Springer.

Schulte-Werning, B., Thompson, D., Gautier, P. E., Hanson, C., Hemsworth, B., Nelson, J., et al. (2008). Noise and vibration mitigation for rail transportation systems. In Notes on numerical fluid mechanics and multidisciplinary design (Vol. 99).

Schweinsberg, F., Abke, W., Rieth, K., Rohmann, U., \& Zullei-Seibert, N. (1999). Herbicide use on railway tracks for safety reasons in Germany? Toxicology Letters, 107, 201-205.

Snyder, E. B., Arango, C. P., Eitemiller, D. J., Stanford, J. A., \& Uebelacker, M. L. (2002). Floodplain hydrologic connectivity and fisheries restoration in the Yakima River, USA. Internationale Vereinigung für Limnologie, 28, 1653-1657.

Stoll, S. (2013). How site characteristics, competition and predation influence site specific abundance of sand lizard on railway banks. Dissertation. Universität Bern.

Tiwari, A., Kadu, P., \& Mishra, A. (2013). Study of noise pollution due to railways and vehicular traffic at level crossing and its remedial measures. American Journal of Engineering Research, 2, 16-19.

Trewhella, W. J., \& Harris, S. (1990). The effect of railway lines on urban fox (Vulpes vulpes) numbers and dispersal movements. Journal of Zoology, 221, 321-326.

van der Grift, E. A. (1999). Mammals and railroads: Impacts and management implications. Lutra, 42, 77-79.

Vandevelde, J. C., Bouhoursc, A., Julien, J. F., Couvet, D., \& Kerbiriou, C. (2014). Activity of European common bats along railway verges. Ecological Engineering, 64, 49-56.

Van Renterghem, T., \& Botteldooren, D. (2012). On the choice between walls and berms for road traffic noise shielding including wind effects. Landscape and Urban Planning, 105, 199-210.

van Rooyen, C. (2009). Bird impact assessment study Kusile railway line and associated infrastructure. Report, Robindale.

Vo, P. T., Ngo, H. H., Guo, W., Zhou, J. L., Listowski, A., Du, B., et al. (2015). Stormwater quality management in rail transportation-Past, present and future. Science of the Total Environmnet, 512, 353-363.

Waterman, E., Tulp, I., Reijnen, R., Krijgsveld, K., \& Braak, C. (2002). Disturbance of meadow birds by railway noise in The Netherlands. Geluid, 1, 2-3.

Wells, P. (1996). Wildlife mortality on the Canadian Pacific Railway between Field and Revelstoke, British Columbia. Unpublished report.

Wiacek, J., Polak, M., Filipiuk, M., Kucharczyk, M., \& Bohatkiewicz, J. (2015). Do birds avoid railroads as has been found for roads? Environmental Management, 56, 643-652.

Wiłkomirski, B., Sudnik-Wójcikowska, B., Galera, H., Wierzbicka, M., \& Malawska, M. (2011). Railway transportation as a serious source of organic and inorganic pollution. Water, Air, and Soil pollution, 218, 333-345.

Wilkomirski, B., Galera, H., Sudnik-Wójcikowska, B., Staszewski, T., \& Malawska, M. (2012). Railway tracks-habitat conditions, contamination, floristic settlement-a review. Environment and Natural Resources Research, 2, 86.

Wilson, L. D., \& Porras, L. (1983). The ecological impact of man on the south Florida herpetofauna. University of Kansas Museum of Natural History, Special Publication, 9, 89. 
Xia, L., Yang Q., Li Z., Wu, Y., \& Feng, Z. (2007). The effect of the Qinghai-Tibet railway on the migration of Tibetan antelope Pantholops hodgsonii in Hoh-xil National Nature Reserve, China. Oryx, 41, 3.

Xu, X., Zhang, K., Kong, Y., Chen, J., \& Yu, B. (2006). Effectiveness of erosion control measures along the Qinghai-Tibet highway, Tibetan plateau, china. Transportation Research Part D: Transport and Environment, 11, 302-309.

Zhang, H., Wang, Z. F., Zhang, Y. L., \& Hu, Z. J. (2012). The effects of the Qinghai-Tibet railway on heavy metals enrichment in soils. Science of the Total Environment, 439, 240-248.

Open Access This chapter is licensed under the terms of the Creative Commons Attribution 4.0 International License (http://creativecommons.org/licenses/by/4.0/), which permits use, sharing, adaptation, distribution and reproduction in any medium or format, as long as you give appropriate credit to the original author(s) and the source, provide a link to the Creative Commons license and indicate if changes were made.

The images or other third party material in this chapter are included in the chapter's Creative Commons license, unless indicated otherwise in a credit line to the material. If material is not included in the chapter's Creative Commons license and your intended use is not permitted by statutory regulation or exceeds the permitted use, you will need to obtain permission directly from the copyright holder.

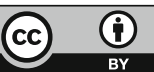

